\section{Greetings to the Blue Jay Members}

Eleanor Denlinger, Lemon Grove, California.

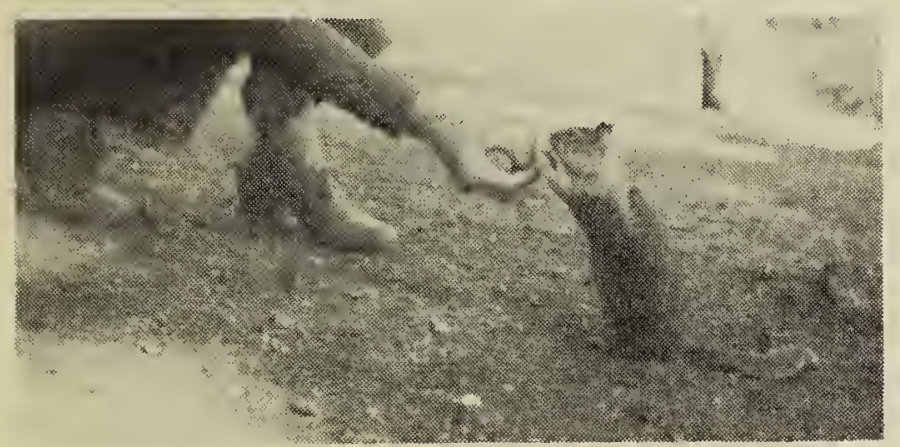

Having enjoyed this little magazine for two years now I thought I'd better tell you how much I appreciate it.

You see I am an Ex-Canadian, and I started reading this magazine through the kindness of a very old and dear friend of mine, Doug Gilroy, whom I lived near for several years-many years ago.

Three years ago, May, I visited Regina and Condie after a fourteen year absence. While there I renewed many friendships among the people as well as the wild life and botanical life of my old birthplace. It was really thrilling to poke abut here and there down by the creek where I once had spent many happy hours. I relived many a happy experience over that two-week visit, and also enjoyed many of the pictures that Doug had taken on his tours of prairie, valley and farm.

Here in California, we have many pretty birds, wild deer in the mountains and also tamed ones in our protected parks. Even the little Chipmunks at Yosemite National Park will feed from your hand. At first I was a bit skeptical, but my fears took wing and soon he was sitting with his paws in my hand, contentedly nibbling raisin nut bread.

\section{The Duck with One Foot Mrs. W. J. Bobier, Rapid View}

One day in the spring of 1950, the boys brought home a Mallard Duck that they had found caught in a muskrat trap. They wanted to keep it for a pet. The duck was healthy and strong but one foot was nearly severed just below the small back toe. There was little chance of the leg healing as nearly half an inch of bone protruded beyond the flesh.

If the boys wanted to keep it, something had to be done. As I had before mended hens' broken legs, I decided to do what I could for the duck. With the hacksaw I cut off a piece of the bone and sewed the loose flesh over the end. I bound wooden splints securely in place so that the stump was protected.

We put our duck in an unused chicken-run, she seemed quite satisfied and ate the barley that the boys provided. On the fourth morning she was gone.

I often wondered if she had survived. If so, how did she manage to swim-handicapped like that? If she could swim, would it always be in a circle?

Last October I had my first question answered. One day the boys brought in some ducks they had shot. There was my one-footed duck! There could be no doubt about it as the skin was healed over the end of the bone, just as I remembered having sewn it. Our duck had lived alright, but I am still wondering if she had to swim in circles.

\section{A Noticeable Change Mrs. Arthur Thompson, R.R. 1, Bangor}

There has been quite a change in the bird life around this district during the forty years I have lived here. Blue Jays, Canada Jays, Snipes, Bobolinks, Mourning Doves and Partridges used to be numerous, and now are rarely seen. I saw a Blue Jay on the south hill of the Qu'Appelle, at No. 9 highway this fall, the first I have seen in 16 years.

In the last few years Blue Birds have become very numerous and now nest in our bird houses. I saw the first pair 14 years ago. Magpies have moved in and are plentiful. I saw my first Blue Heron last fall, and the first Burrowing Owl, last summer. Their nest was near the road, and the comical little birds would perch on the mound of earth at the entrance to their burrow, or fly to the nearby fence post and stare solemnly at us as we drove slowly by.

Several times last summer a doe had been seen on our fields with three little fawns-even when crossing wide open fields. We are sure they are triplets. 